\title{
A new epilithic stream species in Northeastern Brazil: Arnoldiella elbakyaniae (Cladophorales, Chlorophyta)
}

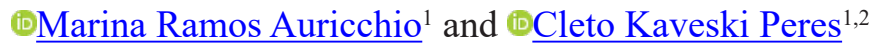

Received: 27 January 2019; accepted: 15 August 2019

How to cite: Auricchio, M.R., Peres, C.K. 2019. A new epilithic stream species in Northeastern Brazil: Arnoldiella elbakyaniae (Cladophorales, Chlorophyta). Hoehnea 46: e312019. http://dx.doi.org/10.1590/2236-8906-31/2019.

ABSTRACT - (A new epilithic stream species in Northeastern Brazil: Arnoldiella elbakyaniae (Cladophorales, Chlorophyta)). Arnoldiella elbakyaniae sp. nov. is described based on epilithic material collected in a cascade of a stream in Northeastern Brazil, Piauí State. The stream belongs to the Parnaíba river basin, which encompasses one of the most poorly sampled regions in the country. We also propose here the combination of Basicladia emedii C.K. Peres \& C.C.Z. Branco into Arnoldiella emedii comb. nov., following the new arrangement proposed for the group. Arnoldiella elbakyaniae can be recognized by the heterotrichous thallus with short erect, unbranched or sparsely branched filaments, and by the short and enlarged basal cells of the erect system. The new species differs from A. emedii by its shorter basal cells, the narrower and cylindrical axis cells, and the zoosporangia in terminal chains.

Keywords: Arnoldiella emedii, Caatinga, green algae, lotic, tropical

RESUMO - (Uma nova espécie epilítica de riachos no Nordeste do Brasil: Arnoldiella elbakyaniae (Cladophorales, Chlorophyta)). Arnoldiella elbakyaniae sp. nov. é descrita com base em material epilítico coletado em uma cascata de um riacho no nordeste brasileiro, Estado do Piauí. O riacho pertence à bacia do rio Parnaíba que é uma das regiões mais pobremente amostradas no país. Apresentamos aqui também uma nova combinação de Basicladia emedii C.K. Peres \& C.C.Z. Branco em Arnoldiella emedii comb. nov. seguindo o arranjo proposto para o grupo. Arnoldiella elbakyaniae pode ser reconhecida por um talo heterotríqueo com filamentos eretos pequenos, não ramificados ou esparsamente ramificados $\mathrm{e}$ célula basal do sistema ereto curta e larga. Difere de A. emedii pelas suas células basais mais curtas, pelas células do eixo mais estreitas e cilíndricas e pelos zoosporângios em cadeias terminais.

Palavras-chave: Arnoldiella emedii, Caatinga, algas verdes, lótico, tropical

\section{Introduction}

Arnoldiella V.V. Mill. emend Boedeker (Cladophorales, Chlorophyta) is a genus that encompasses filamentous green algae characterized by a heterotrichous thallus, differentiated in a prostrate layer consisting of coalescent filaments (usually with uninucleate cells) and erect filaments densely or sparsely branched constituted by coenocytic cells (Boedeker et al. 2012). In addition, others characteristics can be used for the genus identification, such as cells gradually becoming shorter and wider from base to apex, apical cells rounded and pointed, thick cell wall, and terminal zoosporangia (Boedeker et al. 2012).
In the description by Boedeker et al. (2012), which is supported by molecular data of the entire 'Aegagropila' clade, the genus broadens its configuration by also covering the majority of species treated traditionally as Basicladia Hoffman \& Tilden, including the type species of the genus, $B$. crassa W.E. Hoffman \& Tilden. Thus, Basicladia species have been regrouped in Arnoldiella chelonum (Collins) Boedeker, Arnoldiella crassa (W.E. Hoffm. \& Tilden) Boedeker, Arnoldiella kosterae (C. Hoek) Boedeker, Arnoldiella sinensis (N.L. Gardner) Boedeker, and Arnoldiella vivipara (Normandin \& Taft) Boedeker. Therefore, this group with new combinations plus the type species of the genus Arnoldiella, A. conchophila

1. Universidade Federal da Integração Latino-Americana, Grupo de Pesquisa em Biodiversidade e Ecologia de Riachos, Programa de Pós-Graduação em Biodiversidade Neotropical, Av. Tarquínio J. dos Santos, 1000, CEP: 85870-901, Foz do Iguaçu, Paraná, Brasil

2. Corresponding author: cletoperes@yahoo.com.br 
V.V. Miller, and the recently described $A$. wuhanensis G.-X.Liu \& Z.G.Hu corresponds to the seven species recognized in the genus (Guiry \& Guiry 2018). Despite that, two species of Basicladia, B. ramulosa Ducker and B. okamurae (S. Ueda) Garbary, did not appear in the 'Arnoldiella' clade due to the lack of support and paraphyly, respectively. Thus, the authors maintained both species as incertae sedis, with no formal taxonomic designation (Boedeker et al. 2012).

With this new combination proposed by Boedeker et al. (2012), Basicladia temporarily loses its genus status, and its type species, $B$. crassa, is regrouped in $A$. crassa. One species that still depends on analysis is B. emedii C.K. Peres \& C.C.Z. Branco, which was described almost simultaneously to the publication by Boedeker and colleagues, and was therefore not analyzed by the authors. Nevertheless, morphological characters of $B$. emedii, particularly their heterotrichous condition, clearly allow for recognizing it as another Arnoldiella species.

Arnoldiella (= Basicladia) species are typical of the epizoic substrates. A. conchophila, A. vivipara, and $A$. wuhanensis have been described as occurring on snail shells. The other species, although they also occur in epilithic environments, have been particularly described on the carapaces of freshwater turtles (Castillo 1997). Different from the pattern found for the group, B. emedii typically occurs in epilithic environments of Brazilian streams, although always on rocks under the influence of water level fluctuation, which creates an amphibious condition for the growth of algae similar to that found in epizoic environments (Peres \& Branco 2012).

In this paper, we describe Arnoldiella elbakyaniae, a new Cladophorales species from epilithic habitats of streams found in the Brazilian Northeast, one of the regions with the lowest record of algae in the country (Flora do Brasil 2020 under construction 2018). We also formally show the new grouping of Basicladia emedii in Arnoldiella emedii.

\section{Material and methods}

The specimens analyzed were collected (ICMBio, License number 58717-3) in the cascades of Campeira waterfalls in Alto Longá, Piauí State, Brazil $\left(05.182627^{\circ} \mathrm{S}\right.$ and $\left.42.259915^{\circ} \mathrm{W}\right)$, formed by the Boi river, a $3^{\text {rd }}$-order stream which is inserted in the Parnaíba river basin. This region encompasses an ecotone that is under the natural influence of the Caatinga and Cerrado Biomes. The sample was found in a region with few records of algae (Auricchio et al. 2019). Although the analyzed material is abundant, the difficulty of access to the site and the environmental changes that the region has been suffering have not allowed new access to the material.

The material was scraped with a spatula, kept in flasks, preserved in 4\% formaldehyde, and taken to the laboratory for analysis. Characters were taxonomically analyzed using a Zeiss trinocular microscope, AxioLab.A1, coupled with a digital image capture system, while morphometric analyses were performed using the Zen software. Voucher specimens were deposited in liquid medium ( $4 \%$ formaldehyde) at the herbarium of the Universidade Estadual do Oeste do Paraná (UNOP-Algae, Western Paraná State University), Cascavel campus (Holmgren et al. 1990).

\section{Results}

\section{Order Cladophorales}

\section{Family Pithophoraceae}

Arnoldiella elbakyaniae M.R.Auricchio \& C.K.Peres, sp. nov.

Figures 1-16

Holotype - BRAZIL. Piauí: Alto Longá, Campeira waterfall, Boi stream, $05.182627^{\circ} \mathrm{S}$ and $42.259915^{\circ} \mathrm{W}$, 7-VI-2017, P.Auricchio (UNOP-Algae 5634).

Diagnosis - Filaments small (4-9 mm), heterotrichous; prostrate system formed by branched, creeping filaments adhered to rocky substrates; erect filaments with branches generally absent or scarce; basal cell short, cylindrical, nearly quadratic (length/ diameter 1.1-1.5), 34.3-54.3 $\mu \mathrm{m}$ long and 23.3-39.1 $\mu \mathrm{m}$ diameter; cells from the main axis cylindrical, not or slightly constricted, 33.9-48.2 $\mu \mathrm{m}$ long and 30.9-42.4 $\mu \mathrm{m}$ diameter; zoosporangia only in chains in the apex of filaments.

Etymology - The epithet elbakyaniae is a tribute to the scientist and cyberactivist Kazakh Alexandra Elbakyan. Her work and her fight have allowed that science to be accessible to everybody.

Description - Thallus filamentous, heterotrichous, dark green, forming tufts, with 4-9 $\mathrm{mm}$ long $(\bar{x}=5.7 \pm 1.5$; mean \pm s.d. $)$. Prostrate system formed by branched creeping and coalescent filaments adhered to rocky substrates. Prostrate 

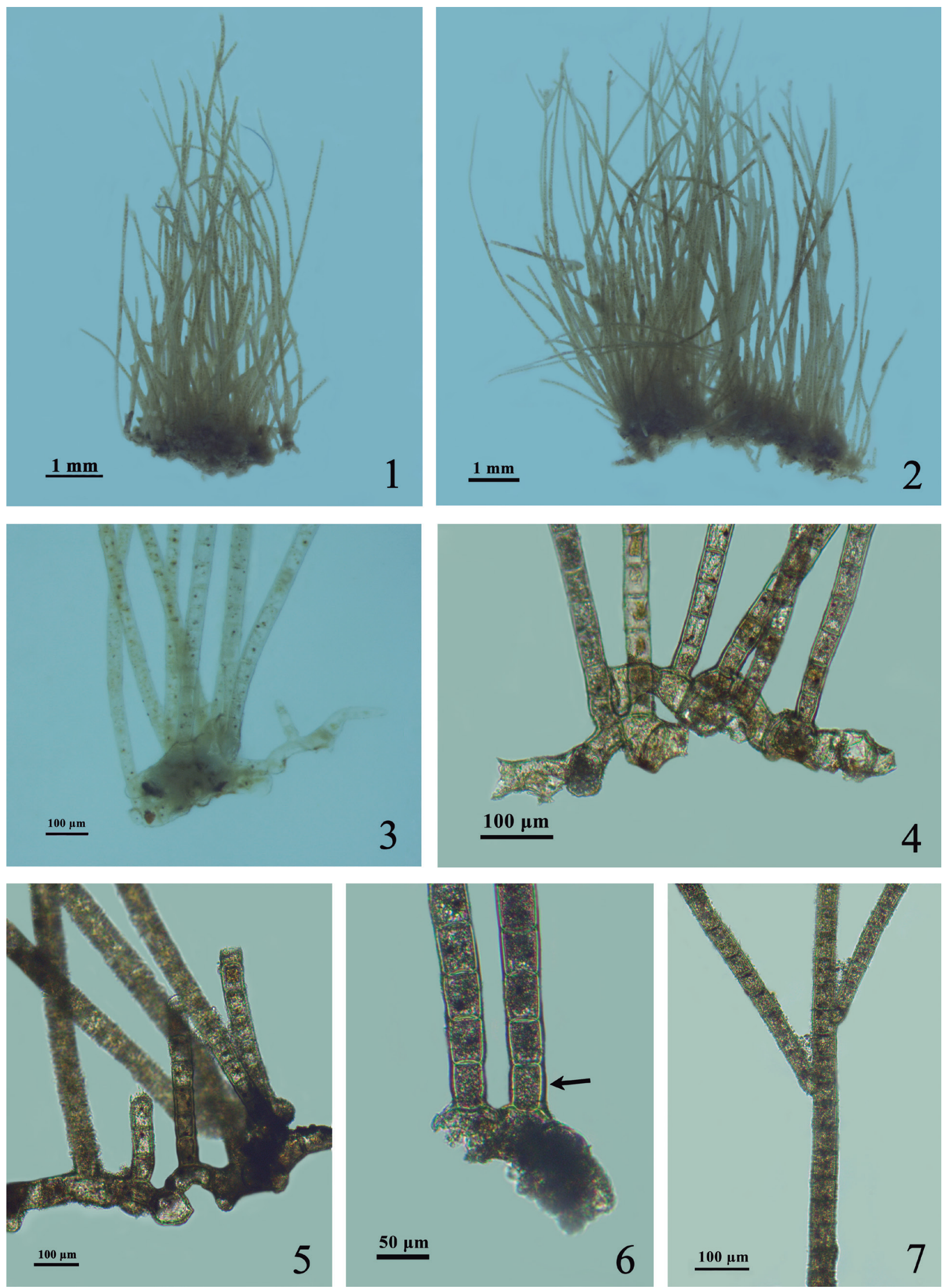

Figures 1-7. Arnoldiella elbakyaniae. 1-2. General view of the heterotrichous thallus. 3-5. Prostrate system. 6. Basal cell (arrow). 7. Branches. 

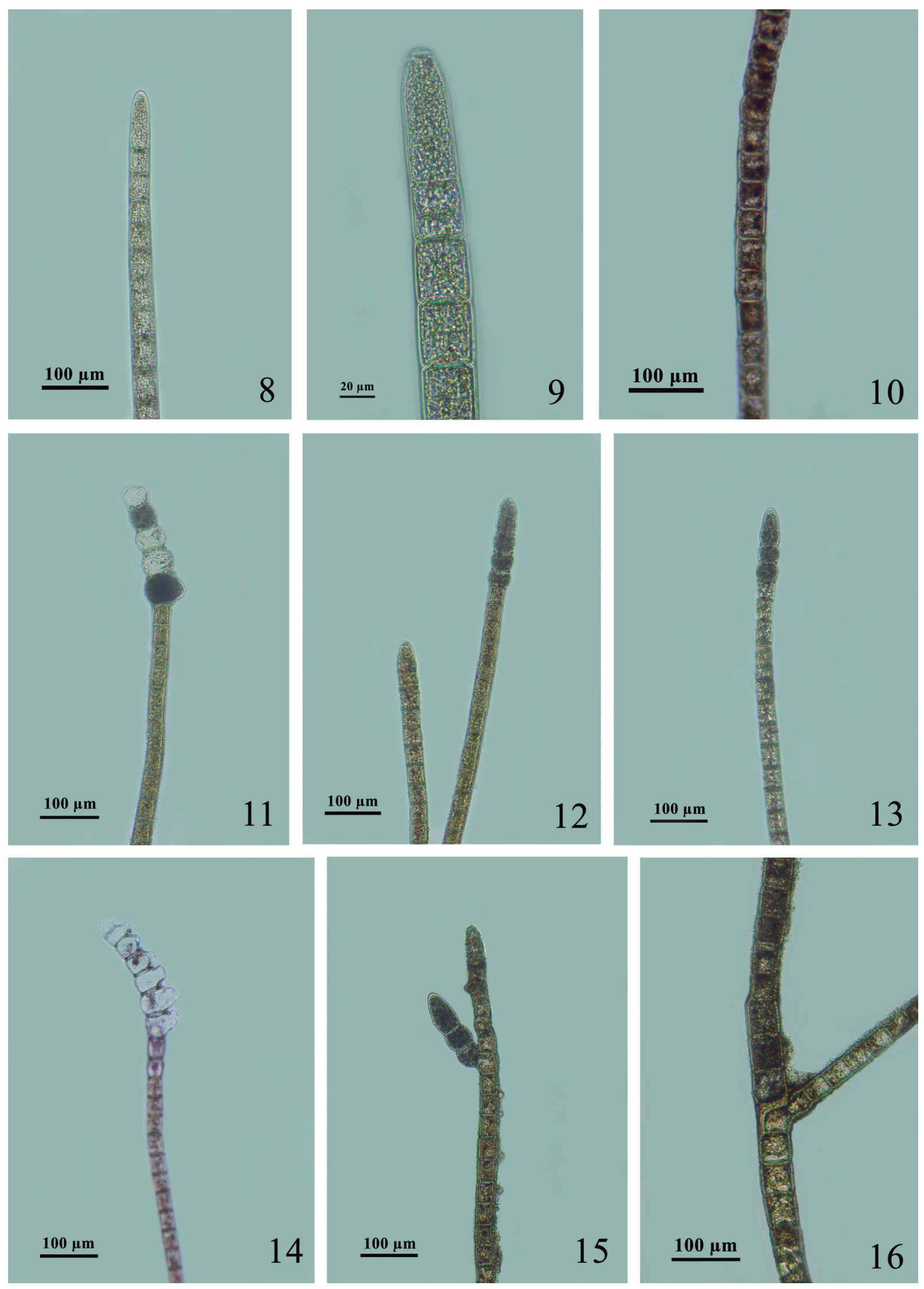

Figures 8-16. Arnoldiella elbakyaniae. 8-9. Erect system with the apical cell. 10. Cells of the erect system. 11-13. Zoosporangia in a terminal chain. 14. Empty zoosporangia with pores. 15-16. Branches. 
system cells irregular, 50.1-74.2 (-122.4) $\mu \mathrm{m}$ long $(\bar{x}=72.1 \pm 19.1),(25.0-) 31.5-53.7 \mu$ m diameter $(\bar{x}=42.9 \pm 9.4)$, length/diameter $1.2-2.3$ $(\bar{x}=1.8 \pm 0.4)$, thick cell walls with (1.3-) 3.4-5.6 $\mu \mathrm{m}(\bar{x}=4.1 \pm 1.2)$. Scarce rhizoids arise from the prostrate system and rarely from the erect filaments. Erect system formed by short or long filaments (23-120 cells), thick cell walls with $2.5-4.2 \mu \mathrm{m}$ $(\bar{x}=3.3 \pm 0.5)$. Basal cell of main axis cylindrical, equal or slightly narrower than other axis cells, 34.3-54.3 $\mu \mathrm{m}$ long $(\bar{x}=42.9 \pm 6.6), 23.3-39.1 \mu \mathrm{m}$ diameter $(\bar{x}=31.6 \pm 4.5)$, length/diameter 1.1-1.5 $(\bar{x}=1.3 \pm 0.1)$. Cells of main axis cylindrical, not or slightly constricted in the septa, 33.9-48.2 $\mu \mathrm{m}$ long $(\bar{x}=41.8 \pm 4.9), 30.9-42.4 \mu \mathrm{m}$ diameter $(\bar{x}=35.1 \pm 4.3)$, length/diameter 1.0-1.4 $(\bar{x}=1.2 \pm 0.2)$. Apical cells acuminate or rounded, usually longer than axial cells, (50.1-) 67.1-108.5 $\mu \mathrm{m}$ long $(\bar{x}=81.1 \pm 18.2), 26.6-35.8(-55.7) \mu$ m diameter $(\bar{x}=33.7 \pm 8.2)$, length/diameter (0.9-) 1.9-3.4 $(\bar{x}=2.4 \pm 0.7)$. Branches in erect system absent or scarce (occurring in less than $10 \%$ of filaments), without a particular position on the filament, unilateral, inserted in a subterminal position in the branched cell. Chloroplast parietal, reticulate, with some pyrenoids. Zoosporangia in chains of 3-7, differentiated from the other cells of the main axis, moniliform, usually at the apex of erect filament, occasionally occur inserted at subterminal position on erect system cells, 30.5-53.9 $\mu \mathrm{m}$ long $(\bar{x}=39.6 \pm 8.1), 42.9-61.2(-71.3) \mu \mathrm{m}$ diameter $(\bar{x}=51.3 \pm 9.3)$, length/diameter 0.6-0.8 $(\bar{x}=0.7 \pm 0.1)$, with a single lateral pore located in median position, pore diameter $11.2-27.8 \mu \mathrm{m}$ $(\bar{x}=19.1 \pm 4.6)$.

\section{Discussion}

Taxonomic notes - The analysis by Peres \& Branco (2012) of the characters shown by Basicladia emedii and the configuration of the genus Arnoldiella by Boedeker et al. (2012) allow for a new combination of the species, described as follows:

Arnoldiella emedii (C.K.Peres \& C.C.Z.Branco) C.K.Peres \& M.R.Auricchio comb. nov.

Basionym - Basicladia emedii C.K.Peres \& C.C.Z.Branco

Cryptogamie Algologie 33(4): 329-337. Figures 1-16. 2012.

Holotype - BRAZIL, Paraná: Céu Azul, Iguaçu

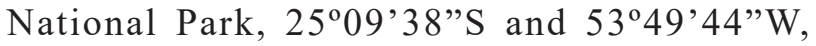

2-V-2008; unnamed stream, C.C.Z. Branco et al. [SJRP Herbarium (UNESP) 29760].

In the material analyzed here, the presence of heterotrichous thallus, the prostrate system formed by branched, creeping coalescent filaments, the thick cell wall, and the erect system with terminal zoosporangia agree perfectly with the description by Boedeker et al. (2012) of the genus Arnoldiella. The same authors described the erect filaments of the genus Arnoldiella as having cells gradually shorter and wider from base to apex. In A. elbakyaniae, the cells do not clearly show these characteristics maintaining the same proportion along the filament.

Peres \& Branco (2012) showed a comparative chart with most Arnoldiella species (cited as Basicladia) and Basicladia ramulosa and B. okamurae, species which are apparently related phylogenetically (according to Boedeker et al. 2012). Comparing the characters, it is clear that $A$. emedii is the most morphologically similar to $A$. elbakyaniae. Both species encompass small plants with a maximum of $9 \mathrm{~mm}$ length, although they are larger than $A$. conchophilla and $A$. vivipara, which reach up to a maximum of $1 \mathrm{~mm}$, A. conchophilla and A. vivipara have both been exclusively documented as having an epizoic habit on mollusk shells. Additionally, following the pattern of $A$. emedii, A. elbakyaniae is sparsely branched, differing from $A$. kosterae as well as from Basicladia ramulosa and $B$. okamurae. Moreover, similar to $A$. emedii, its basal cell is short (maximum $122.4 \mu \mathrm{m}$ ), differing from most of the species in the genus and related species, which have basal cells larger than $550 \mu \mathrm{m}$ (e.g. A. chelonum, A. crassa, A. kosterae, Basicladia ramulosa, and $B$. okamurae).

Although there are morphological similarities between them (compared to other species), $A$. elbakyaniae clearly differs from $A$. emedii in some important aspects: i) basal cell is shorter (34.3-54.3 $\mu \mathrm{m}$ vs. $45.9-121.8 \mu \mathrm{m}$ in A. emedii); ii) the cells of the main axis of the erect system are cylindrical, with no more than a slight constriction in the septa, whereas cells in A. emedii are strongly constricted and moniliform; iii) cells of the main axis have a smaller diameter (30.9-42.4 $\mu \mathrm{m} v s$. 56.8-176.0 $\mu \mathrm{m}$ in A. emedii); iv) zoosporangia occur in terminal chains, in groups of 3-7, whereas in $A$. emedii they also occur in intermediate portions of the filament, either in chains or alone.

Environmental features - The populations used to describe the species were collected from marginal rocky substrates, in a cascade environment. Rainfall in the region shows a very sharp seasonality (Brazil 
2006); therefore, during the dry season, riffles are interrupted and most of the specimens are prone to desiccation. This habit is quite similar to that found in A. emedii by Peres \& Branco (2012), where the authors mention that the water level oscillation in the rocks might cause an amphibious condition, which potentially favors the establishment of this species. Therefore, although A. emedii and A. elbakyaniae are epilithic, they might simulate the amphibious epizoic habit widely disseminated in the other species of this genus during their growth on the rock substrates.

The stream where the specimens were collected is a tributary of the Parnaíba river basin. According to the data surveyed from the Flora do Brasil 2020 under construction (2018), this river basin has had the lowest number of algal species recorded so far. Therefore, the description of this species reinforces the importance of efforts to gain insight into biodiversity, thus contributing to reducing conservation shortfalls (Lomolino 2004).

This description comprises the third record of the genus in South America. Along with A. emedii, which has been recently described in Southern Brazil and, A. chelonum was the first species to be documented (Semir et al. 1988, as Basicladia chelonum), occurring on carapaces of turtles in the São Paulo State, Southeastern Brazil.

\section{Acknowledgments}

The authors are grateful to ICMBio for authorizing the sampling (SISBIO: 58717-1), to UNILA (Edital PRPPG 109) for financial support, and to Paulo Auricchio for help in collecting the specimens and making them available for identification and description.

\section{Literature cited}

Auricchio, M.R., Lambrecht, R.W. \& Peres, C.K. 2019. Stream macroalgal flora from Parnaíba River Basin, Brazil: reducing Wallacean shortfall. Biota Neotropica 19: e20180685.
Boedeker, C., O'Kelly, C.J., Star, W. \& Leliaert, F. 2012. Molecular phylogeny and taxonomy of the 'Aegagropila' clade (Cladophorales, Ulvophyceae), including the description of Aegagropilopsis gen. nov. and Pseudocladophora gen. nov. Journal of Phycology 48: 808-825.

Brazil. 2006. Ministério do Meio Ambiente: Caderno da Região Hidrográfica do Parnaíba. Plano Nacional de Recursos Hídricos. Brasília.

Castillo, M.E.A.M. 1997. Taxonomia y distribución de las Cladophorales (Chlorophyta) en la región de la Huasteca Potosina. Tese de Doctorado. Universidade Nacional Autônoma de México.

Ducker, S.C. 1958 Anew species of Basicladia on Australian freshwater turtles. Hydrobiologia 10: 157-174.

Flora do Brasil 2020 under construction. 2018. Jardim Botânico do Rio de Janeiro. Available in http:// floradobrasil.jbrj.gov.br/ (access in 12-VI-18).

Garbary, D.J. 2010. Taxonomy of Basicladia (Cladophorales, Chlorophyta) with two new combinations. Novon 20: 38-40.

Guiry, M.D. \& Guiry, G.M. 2018. AlgaeBase. World-wide electronic publications, National University of Ireland, Galway. Available in http://www.algaebase.org/ (access in 07-VII-18).

Hoffmann, W.E. \& Tilden, J.E. 1930. Basicladia, a new genus of Cladophoraceae. Botanical, Gazette 89: 374-384.

Holmgren, P.K., Holmgren, N.H. \& Barnett, L. 1990. Index herbariorum. Part 1: The herbaria of the world. 8th ed. New York, New York Botanical Garden.

Liu, G.-X. \& Hu, Z.G. 2012. Flora algarum sinicarum aquae dulcis. Tomus XV. Chlorophyta: Chlorooccales (II): Tetrasporales, Dichotomosiphonales, Cladophorales. pp. i-xvii, 1-166, 93 pls. Beijing: Science Press.

Lomolino, M.V. 2004. Conservation biogeography. In: M.V. Lomolino \& L.R. Heaney (eds) Frontiers of biogeography. Sinauer. Sunderland, United Kingdom.

Miller, V. 1928. Arnoldiella, eine neue Cladophoraceaeengattung. Planta 6: 1-21.

Peres, C.K. \& Branco, C.C.Z. 2012. Basicladia emedii (Cladophorales, Chlorophyta): a new freshwater epilithic species from Brazil. Cryptogamie Algologie 33: 329-337.

Semir, J., Sazima, I. \& Sazima, M. 1988. Basicladia chelonum, alga epizoária em casco de tartarugas de água doce, no sudeste brasileiro. Ciência e Cultura 40: 885-888. 